Л. Б. Бондаренко ${ }^{1}$, Т. А. Карацуба ${ }^{1}$, О. О. Хавич ${ }^{1}$, Г. М. Шаяхметова ${ }^{1}$, Н. І. Шарикіна ${ }^{1}$, В. М. Коваленко, О. І. Харченко ${ }^{2}$, Н. М. Сергійчук ${ }^{3}$, М. М. Калачінська ${ }^{3}$

\title{
Вплив 2-(3-аліл-4-оксо-3,4-дигідро-хіназолін- 2-іл-сульфоніл)-N-(2,6-дихлорфеніл)-цераміду на складові хроматину та стан антиоксидантної системи в саркомі 45 і незмінених тканинах шкіри щурів
}

\author{
${ }^{1}$ Державна установа «Інститут фармакології та токсикології \\ Національної академії медичних наук України», м. Київ \\ ${ }^{2}$ Навчально-науковий центр «/нститут біології та медицини» \\ Київського національного університету імені Тараса Шевченка \\ ${ }^{3}$ Відкритий міжнародний університет розвитку людини «Україна», м. Київ
}

Ключові слова: 2-(3-аліл-4-оксо-3,4дигідро-хіназолін-2-іл-сульфоніл)-N-(2,6дихлорфеніл)-церамід, саркома 45, ДНК, РНК, фрагментація, антиоксидантна система

Стрімке поширення онкологічних захворювань у XXI столітті в усьому світі зумовлюе інтенсифікацію хіміотерапевтичного лікування даної патології зі застосуванням все нових i нових цитотоксичних і цитостатичних агентів [1]. Однак це зумовлюе зростання й числа побічних ефектів i небажаних наслідків використання даних препаратів [2]. Неспецифічна дія щодо всього організму пацієнта та висока токсичність даної групи лікарських засобів [3, 4], зокрема, їхня кардіо-, нефро- та нейротоксичність [5], а також відсутність достатньої інформації щодо віддалених наслідків введення протипухлинних засобів на стан прилеглих тканин, які не були захоплені інвазією пухлини, зумовлюють нагальну потребу в системному вивченні біохімічних змін не лише в пухлині, але й поза їі межами.

Наразі наявні результати [3-5] свідчать, що часто відбувається сумація наслідків розвитку пухлинного процесу та впливу протипухлинної хіміотерапії на тканини організму, що не мають

(с) Колектив авторів, 2020 ознак неопластичного процесу, яка ще більше погіршує стан організму, ставлячи його на межу виживання.

У попередніх експериментах нами було проведене вивчення впливу протипухлинного похідного хіназоліну на складові хроматину, процеси фрагментації ДНК, вміст небілкових і пов'язаних 3 білками SH-груп у карциномі Герена та незмінених тканинах матки й виявлено специфічність його впливу стосовно низки показників [6].

У зв'язку з цим актуальним $є$ з'ясування, чи $є$ виявлена специфічність похідних хіназоліну характерною лише для тканини матки, чи вона поширюється й на інші тканини організму.

Мета дослідження - вивчити вплив 2-(3-аліл-4-оксо-3,4-дигідро-хіназолін2 -іл-сульфоніл)-N-(2,6-дихлорфеніл)цераміду (АХДЦ) на ДНК, РНК, білки хроматину, процеси фрагментації ДНК, вміст небілкових і пов'язаних з білками SH-груп у саркомі 45 і незмінених тканинах шкіри щурів.

Матеріали та методи. Дослідження впливу АХДЦ проводили на білих щурах - самицях лінії Вістар масою 150-250 г, вирощених у віварії ДУ «Інститут фармакології та токсикології НАМНУ». Тварин утримували на стандартному харчовому раціоні за умов вільного доступу до води. План досліджень був розглянутий та схвалений 
Комітетом 3 біоетики ДУ «Інститут фармакології та токсикології НАМНУ „, усі процедури, пов'язані з гуманним поводженням 3 тваринами та їхнім використанням в експериментах, були дотримані. Тварин розподіляли на групи за методом рандомізації з попереднім карантином протягом 7 діб. АХДЦ було синтезовано у відділі медичної хімії ДУ «Інститут фармакології та токсикології НАМНУ " та попередньо охарактеризовано як перспективну сполуку 3 протипухлинною активністю [7].

Вплив АХДЦ на складові хроматину та стан антиоксидантної системи вивчали за умов експериментальної моделі саркоми 45, яку одержували шляхом трансплантації тваринам за стандартними методами [8]. Тварини були розподілені на 3 групи по 6 тварин у кожній: 1 - інтактні щури; 2 - негативний контроль (саркома 45); 3 - саркома $45+$ АХДЦ (29,93 мг/кг). Тваринам III групи перорально вводили АХДЦ, а щурам I і II груп - відповідний об'єм $0,9 \%$ водного розчину хлориду натрію. Введення проводили кожні 48 год, починаючи 3 наступної доби після трансплантації саркоми 45, протягом двох тижнів. На 15 добу експерименту тварин зважували, знеживлювали методом цервікальної дислокації й вилучали пухлини та відповідні тканини без неопластичних змін для подальших досліджень.

Заморожені в рідкому азоті тканини гомогенізували та виділяли геномну ДНК, РНК і білки [9].

Для виділення нуклеїнових кислот гомогенізацію зразка (50 мкг) проводили в 1 мл TRI-реагенту («Sigma», CША), після чого додавали 200 мкл хлороформу, струшували та залишали стояти за кімнатної температури протягом 15 хв. Далі центрифугували $\left(12000 \mathrm{~g}, 2{ }^{\circ} \mathrm{C}\right.$, $15 \mathrm{xв),} \mathrm{після} \mathrm{чого} \mathrm{розчин} \mathrm{розділився} \mathrm{на}$ три фази: червону (білки), білу (містить ДНК) і безбарвну фазу (містить РНК). Фракції акуратно розшаровували окремо по пробіркам для подальшого очищення та визначення вмісту.

Для виділення РНК у мікропробірку з відібраною безбарвною фазою додавали 0,5 мл ізопропанолу, відстоювали 5-10 хв за кімнатної температури та центрифугували (12 $000 \mathrm{~g}, 2{ }^{\circ} \mathrm{C}, 10$ хв), зливали супернатант. До осаду додавали $75 \%$ етанол до об'єму 2 мл, центрифугували за $12000 \mathrm{~g}, 2{ }^{\circ} \mathrm{C}, 5$ хв, зливали супернатант. Процедуру повторювали двічі. Одержаний зразок РНК висушували та розводили в 100 мкл DEPCводи.

Для виділення ДНК в епендорф 3 відібраною фракцією додавали 0,3 мл $100 \%$ етанолу, відстоювали $2-3$ хв за кімнатної температури, центрифугували $\left(2000 \mathrm{~g}, 2{ }^{\circ} \mathrm{C}, 5 \mathrm{xв}\right)$, зливали супернатант. До осаду додавали розчин 0,1 моль/л цитрату натрію в $10 \%$ етанолі (2 мл), відстоювали 30 хв, центрифугували за тих самих умов, зливали супернатант. Осад промивали 2 рази в $70 \%$ етанолі, як зазначено вище, та висушували. Одержаний зразок ДНК висушували та розводили в 100 мкл DEPC-води.

Спектрофотометричне визначення концентрації ДНК і РНК проводили за загальноприйнятим методом [10]. Вимірювали поглинання світла за довжини хвилі 260 нм. Розрахували концентрацію ДНК, використовуючи коефіцієнт перерахунку 6,5 за формулою:

$$
\mathrm{C}_{\text {днк }}\left[\text { мкг/мл] }=\mathrm{A}_{260} 6,5\right. \text {. }
$$

Аналогічно проводили визначення вмісту РНК і розрахували їі концентрацію, використовуючи коефіцієнт перерахунку 5,2 за формулою:

$$
\mathrm{C}_{\text {Рнк }} \text { [мкг/мл] }=\mathrm{A}_{260} 5,2 \text {. }
$$

Вміст гістонів визначали за модифікованим методом Смирнова Н. В. [11].

Для визначення ступеня фрагментації ДНК, її розчиняли в TBE буфері (10 ммоль/л Tris-HCl, 1 ммоль/л EDTA, $\mathrm{pH} 8$ ) та розділяли в $2 \%$ агарозному гелі 80B; 83 мА, 6 W, 2 год. Після завершення електрофорезу гелі забарвлювали розчином бромистого етидію (5 мкг/мл) і фотографували в УФ-світлі за допомогою системи GelDoc ( «BioRad», США) [12].

У гомогенатах тканин також визначали вміст небілкових і пов'язаних 3 білками SH-груп [13].

Отримані дані представляли як середне значення \pm похибка середнього $(\mathrm{M} \pm \mathrm{m})$. Статистичний аналіз результа- 
тів експерименту проводили з використанням однофакторного дисперсійного аналізу (ANOVA). Різницю між досліджуваними показниками вважали статистично вірогідною в разі $\mathrm{p} \leq 0,05$.

Результати та їх обговорення. Наслідком кількісних і якісних змін внутрішньоклітинних макромолекул (таких як ДНК, РНК, протеїни, ліпіди), які невідворотно супроводжують розвиток будь-якого онкологічного процесу, може бути втрата клітиною їі життєздатності та загибель. Нуклеїнові кислоти, наприклад, є настільки критичними для клітини молекулярними мішенями для низки екзогенних факторів, що в природі існує спеціальна система захисту, яка передбачає їхнє летальне розщеплення індуцибельними ендонуклеазами [14]. Зокрема, фрагментація ДНК є маркером протікання процесів апоптозу в організмі [15].

Результати вивчення впливу саркоми 45 та їі лікування АХДЦ на процеси фрагментації ДНК наведені на рисунку 1 та в таблиці 1.

Як видно з електрофореграм, за умов розвитку пухлини відбувається суттєва інтенсифікація процесів фрагментації ДНК у клітинах.

Якщо в нормальній тканині шкіри відзначено лише 3 фрагменти ДНК 3 довжинами 500, 150 і 20 пар основ, то в тканині саркоми 45 у наших експериментах кількість фрагментів ДНК сягала 28. Із них фрагментів з довжинами молекул від 1000 до 500 пар основ 10; фрагментів із довжинами молекул від 500 до 200 пар основ - 6; фрагментів 3 довжинами молекул від 200 до 20 пар основ - 12. Причому за вмістом переважали фрагменти ДНК з меншими розмірами (від 200 до 20 пар основ).

Лікування АХДЦ призводило до деякого зменшення числа фрагментів ДНК у клітинах саркоми 45 - до 16 і зміни характеру самої фрагментації. Так, з цих 16 фрагментів з довжинами молекул від 1000 до 500 пар основ було 3; фрагментів з довжинами молекул від 500 до 200 пар основ - 5; фрагментів 3 довжинами молекул від 200 до 20 пар основ - 8. Причому за вмістом переважали фрагменти ДНК із найменшими розмірами (від 200 до 20 пар основ).

У неуражених пухлинами тканинах введення АХДЦ призводило до утворення 12 фрагментів ДНК. Із цих 12 фрагментів з довжинами молекул від 1000 до 500 пар основ було 3; фрагментів 3 довжинами молекул від 500 до 200 пар основ - в середньому 2; фрагментів з довжинами молекул від 200 до 20 пар основ - 7. Причому за вмістом переважали фрагменти ДНК з найменшими розмірами (від 200 до 20 пар основ).

Результати визначення процента фрагментації ДНК в експериментальних тварин (табл. 1) свідчать, що як розвиток пухлини, так і саме введення препарату призводили до зростання процента фрагментації ДНК. Спостерігається певна тенденція до зниження процента фрагментації ДНК за умов лікування саркоми 45 АХДЦ.

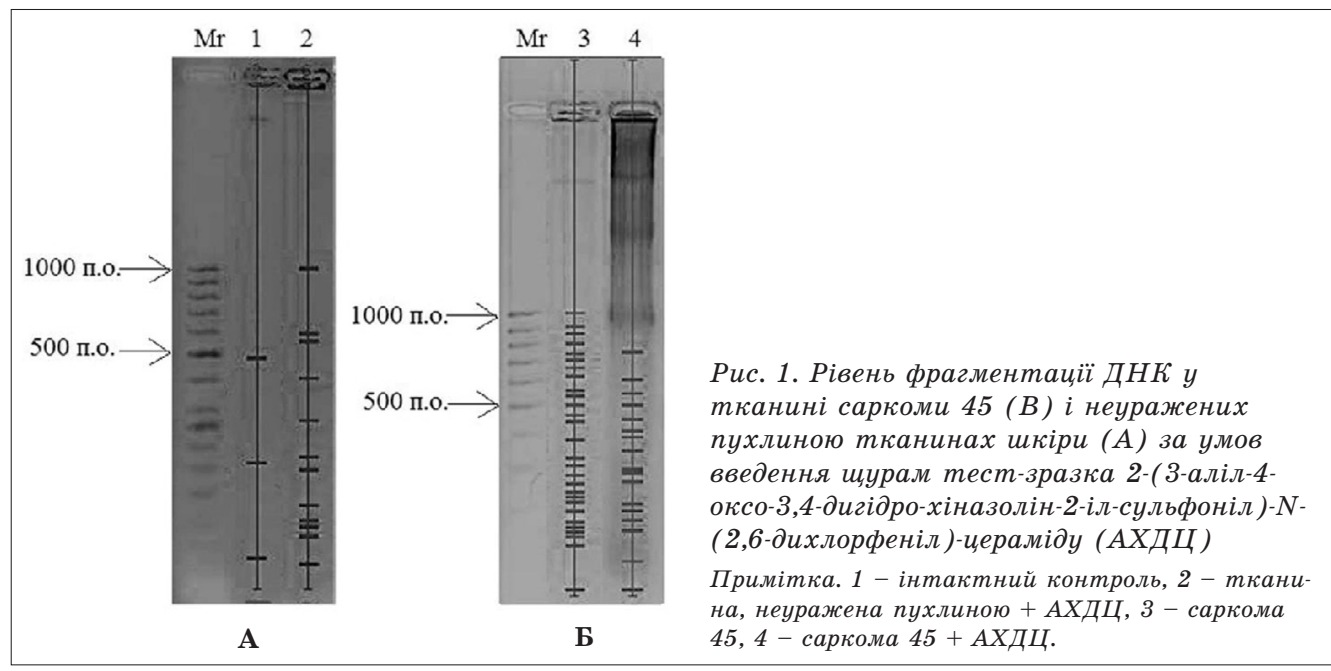


Процент фраглентацї̈ ДНК в експерилентальних тварин

\begin{tabular}{|l|c|c|c|c|}
\hline \multirow{2}{*}{ Показник } & \multicolumn{4}{|c|}{ Експериментальна група } \\
\cline { 2 - 5 } & $\begin{array}{c}\text { тканина шкіри } \\
\text { (інтактний } \\
\text { контроль) }\end{array}$ & $\begin{array}{c}\text { тканина шкіри } \\
\text { (без інвазивного } \\
\text { ураження) + АХДЦ }\end{array}$ & $\begin{array}{c}\text { саркома 45 } \\
\text { (негативний } \\
\text { контроль) }\end{array}$ & $\begin{array}{c}\text { саркома 45 + } \\
\text { АХДЦ }\end{array}$ \\
\hline $\begin{array}{l}\text { Фрагментація } \\
\text { ДНК, \% }\end{array}$ & 11,24 & 57,10 & 55,93 & 57,91 \\
\hline
\end{tabular}

Одержані нами результати цілком узгоджуються з даними інших авторів, які відзначали, що рівень фрагментації ДНК звичайно коливається в межах 5-8 \% у здоровому організмі за нормальних умов, а за умов розвитку навіть передонкологічного процесу відбувається його значне збільшення [16]. Інша група дослідників в експериментах на білих безпородних щурах-самцях показала, що пошкодження ДНК чітко корелювало з ростом пухлин в експериментальних тварин [17].

Окремо слід наголосити на значній подібності впливу похідних хіназоліну на процеси фрагментації ДНК як у карциномі Герена та саркомі 45, так і в прилеглих тканинах, не уражених неопластичними змінами [6]. Це може бути свідченням тканинонезалежного специфічного впливу цитотоксичних сполук хіназолінового ряду на фрагментацію ДНК у клітині. Це припущення узгоджується й $з$ результатами інших авторів, які вивчали вплив іншої сполуки цього ряду (Етопозиду) на клітини пухлин [18]. Етопозид гальмував мітотичну й апоптотичну активність клітин карциноми Герена вже через одну добу застосування, що супроводжувалось збільшенням числа клітин пухлини невеликого розміру [18]. Виходячи з цих даних, можна припустити, що й відзначений нами вплив АХДЦ на ДНК на тлі онкологічного процесу може бути пов'язаний зі здатністю сполуки спричиняти цитотоксичний і цитостатичний ефект на клітини пухлин, що супроводжується пригніченням їхньої мітотичної активності [6, 7, 18]. Крім цього існує можливість реалізації ефекту АХДЦ за рахунок взаємодії з протеїнами з сімейства Bcl-2, що є ключовим регулятором залежного від мітохондрій апоптозу в клітині та включає як антиапоптотичні (Bcl-xL, Bcl-2, Bcl-w, A1, Mcl-1), так і проапоптотичні (Bak, Bax, Bid, Bim , Bad, Bik, Bmf, Noxa, Puma) білки [19]. Такі властивості вже виявлені в низки хімічних сполук, що містять у своїй структурі орто-конденсовані системи (зокрема, карбацефами, гомотієнаміцини) [19].

Не можна виключати й опосередкований вплив цитостатика на процеси фрагментації ДНК за церамід-опосередкованим шляхом [20]. Генерація цієї сполуки є важливим етапом в індукції загибелі пухлинних клітин цитотоксичними агентами. Цитотоксичний ефект протипухлинних агентів пов'язаний з активацією апоптозу через церамід-опосередкований механізм регуляції сигнальної трансдукції запуску процесів диференціювання клітин, арешту клітинного циклу та апоптозу [20]. Показано, що залежно від превалювання цитостатичної чи цитотоксичної активності в ефектах різних протипухлинних препаратів сильно варіює й залученість церамід-опосередкованого механізму до їхнього сумарного впливу на клітину [21]. Зокрема, Етопозид i Таксотер індукують накопичення в тканині пухлини активатора апоптозу ракових клітин цераміду, тоді як цисплатин активує сфінгомієліновий шлях утворення цераміду в пухлинних клітинах [20, 21].

Було досліджено вміст РНК, ДНК, співвідношення РНК/ДНК, вміст РНК відносно загального вмісту нуклеїнових кислот і вміст гістонів у саркомі 45 та за лікування АХДЦ.

Із наведених даних (табл. 2) видно, що статистично вірогідні зміни ДНК за умов розвитку саркоми 45 та їі лікування АХДЦ не відзначалися ні у власне 
Вліст нуклеїнових кислот, їхні співвідношення та вліст гістонів у клітинах сарколи 45 і тканин шкіри без неопластичних змін за умов введення шурал тест-зразка 2-(3-аліл-4-оксо-3,4-дигідро-хіназолін-2-іл-сульфоніл)- $N$ -

(2,6-дихлорфеніл)-иераліду (АХДЦ)

\begin{tabular}{|c|c|c|c|c|}
\hline \multirow[b]{2}{*}{ Показник } & \multicolumn{4}{|c|}{ Експериментальна група } \\
\hline & $\begin{array}{l}\text { тканина шкіри } \\
\text { (інтактний } \\
\text { контроль) }\end{array}$ & $\begin{array}{c}\text { неуражена тканина } \\
\text { шкіри щурів з сар- } \\
\text { комою } 45 \text { + АХДЦ }\end{array}$ & $\begin{array}{c}\text { саркома } 45 \\
\text { (негативний } \\
\text { контроль) }\end{array}$ & $\begin{array}{c}\text { саркома } 45+ \\
\text { АХДЦ }\end{array}$ \\
\hline $\begin{array}{l}\text { Вміст РНК, } \\
\text { мкг/мг білка }\end{array}$ & $12,28 \pm 4,96$ & $31,69 \pm 11,36^{\#, \&}$ & $96,35 \pm 21,09^{*}$ & $64,13 \pm 6,36^{*}$ \\
\hline $\begin{array}{l}\text { Вміст ДНК, } \\
\text { мкг/мг білка }\end{array}$ & $100,45 \pm 1,82$ & $104,93 \pm 0,61$ & $102,60 \pm 0,76$ & $104,93 \pm 0,61$ \\
\hline $\begin{array}{l}\text { Співвідношен- } \\
\text { ня РНК/ДНК }\end{array}$ & $0,12 \pm 0,05$ & $0,30 \pm 0,11^{\#, \&}$ & $0,94 \pm 0,21^{*}$ & $0,61 \pm 0,06^{\star}$ \\
\hline $\begin{array}{l}\text { Співвідношен- } \\
\text { ня РНК та } \\
\text { загального } \\
\text { вмісту нуклеї- } \\
\text { нових кислот }\end{array}$ & $0,10 \pm 0,02$ & $0,22 \pm 0,06^{\#, \&}$ & $0,47 \pm 0,06^{*}$ & $0,38 \pm 0,02^{*}$ \\
\hline $\begin{array}{l}\text { Гістони, мг/мг } \\
\text { тканини }\end{array}$ & $0,38 \pm 0,02$ & $0,44 \pm 0,06^{\#}$ & $0,57 \pm 0,02^{*}$ & $0,45 \pm 0,04^{\star}$ \\
\hline
\end{tabular}

Примітка. *p < 0,05 щодо інтактного контроля; ${ }^{\#} p<0,05$ щодо показників групи з пухлинами без введення препаратів; “р < 0,05 щодо показників групи з пухлинами та введеннял препаратів.

пухлинах, ні в тканинах, не уражених неопластичними змінами. Відбувалось вірогідне зростання вмісту РНК, співвідношення РНК/ДНК, співвідношення РНК до загального вмісту нуклеїнових кислот у саркомі 45 як з лікуванням, так і без, тоді як у тканинах, не уражених неопластичними змінами, ці показники вірогідно не відрізнялися від інтактного контролю. Одночасно спостерігалося вірогідне зростання вмісту гістонових білків за даних умов експерименту, що може свідчити про підвищення жорсткості структури хроматину за пухлинного росту та хіміотерапії даним похідним хіназоліну.

Отримані нами результати цілком узгоджуються 3 даними інших авторів, що показали стабільність кількості ДНК як основного носія генетичної інформації в нормальних соматичних клітинах [22], тоді як кількість РНК, залученої до процесів біосинтезу білка, є варіабельною величиною залежно від віку, життєвої стадії, наявності захворювань і змінюваних умов навколишнього середовища [22]. Клітини, які перебувають у стабільному стані, як правило, мають більш високі співвідношення РНК/ ДНК, ніж ті, які мають відхилення від норми [23], але в неопластичних клітинах відбувається збільшення вмісту РНК і ДНК [24]. Досліди показали, що збільшення кількості нуклеїнових кислот у ракових клітинах може свідчити про підвищення ризику розвитку пухлинних депозитів і закономірно зростає з кожним подальшим етапом метастазування [24].

Дані, наведені в таблиці 2, демонструють тенденцію до зниження вмісту РНК і гістонів у результаті лікування саркоми 45 сполукою АХДЦ порівняно 3 нелікованою пухлиною. Останнє, зокрема, може свідчити про включення механізмів гальмування мітотичного циклу [25] у клітинах пухлини під дією АХДЦ. Одночасно нами виявлено тенденцію до зниження співвідношення РНК/ДНК і РНК/нуклеїнові кислоти (НК), що може свідчити про порушення зростання неопластичних клітин внаслідок застосування досліджуваного агента, оскільки відношення 


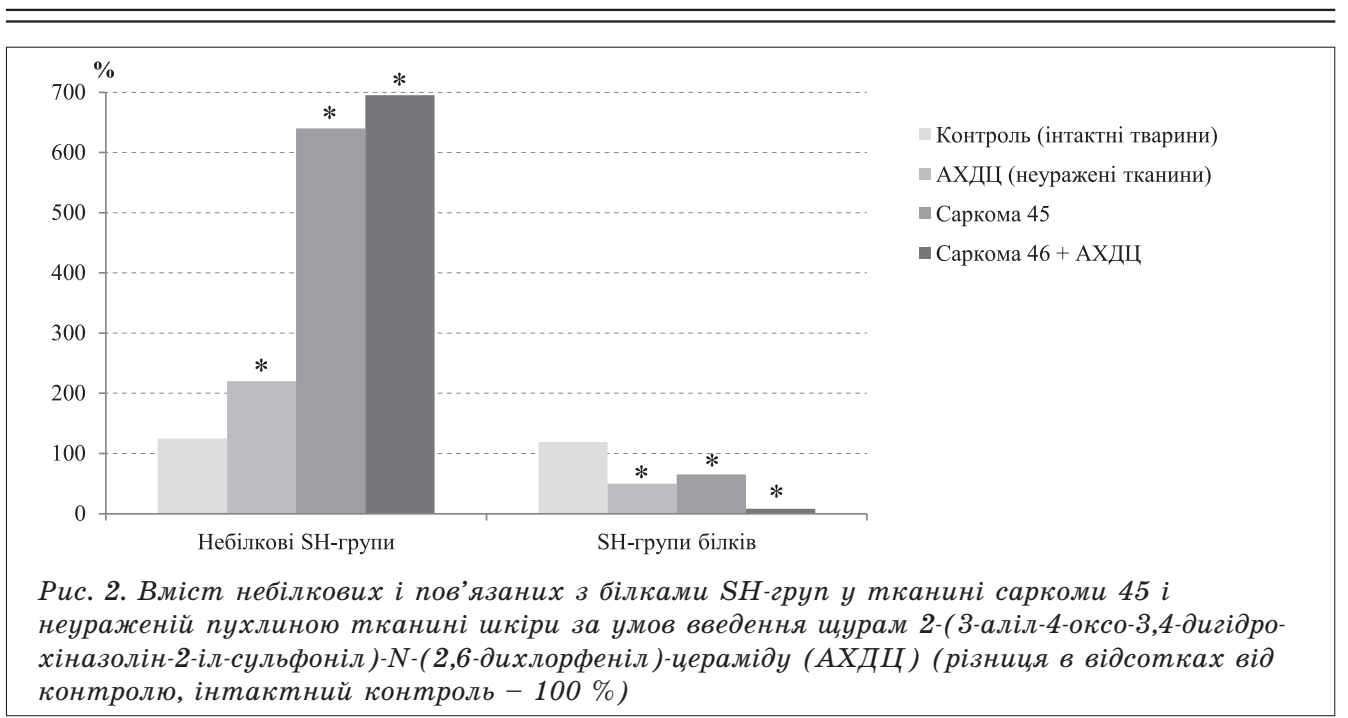

вмісту РНК до загального вмісту нуклеїнових кислот $€$ чутливим маркером будь-яких відхилень від збалансованого клітинного росту [26].

Вірогідні відмінності в ефектах АХДЦ щодо вмісту РНК, співвідношень РНК/ДНК і РНК/НК у тканинах без неопластичних змін й клітинах саркоми 45 свідчить про певну специфічну дію даного препарату виключно на пухлини.

На рисунку 2 наведено результати дослідження вмісту небілкових i пов'язаних з білками SH-груп у тканині саркоми 45 i неуражених пухлиною тканинах за умов введення щурам АХДЦ. За умов розвитку саркоми 45 відбувається суттєве зростання вмісту небілкових i зниження пов'язаних 3

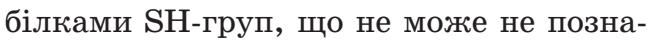
читись на стані систем антиоксидантного захисту клітин організму [27]. Лікування АХДЦ не призводить до нормалізації цих показників у клітинах саркоми 45 і неуражених клітинах шкіри.
Характер ефектів АХДЦ був протилежним за напрямом стосовно змін вмісту небілкових (підвищення) і пов'язаних 3

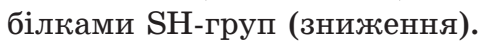

\section{Висновки}

Вивчення впливу АХДЦ на ДНК, РНК, білки хроматину, процеси фрагментації ДНК, вміст небілкових і пов'язаних 3 білками SH-груп у саркомі 45 і незмінених тканинах шкіри показало, що ця сполука вірогідно змінювала більшість досліджуваних показників як порівняно 3 інтактними тваринами, так і з саркомою 45 без лікування. Причому специфічність впливу АХДЦ на клітини пухлин була найвираженішою у випадку ДНК-фрагментації та змін вмісту РНК, співвідношень РНК/ДНК і РНК/НК. Щодо впливу на вміст SH-груп у тканині саркоми 45 і неуражених пухлиною тканинах шкіри, то в даному випадку ефект АХДЦ був протилежним за напрямом стосовно змін вмісту небілкових і пов’язаних з білками SH-груп.

1. Subgroup effects in a randomised trial of different types and doses of exercise during breast cancer chemotherapy. K. S. Courneya, D. C. McKenzie, J. R. Mackey et al. Br J Cancer. 2014. V. 111. P. 1718-25. https://doi.org/10.1038/bjc.2014.466.

2. Nanoscale drug delivery strategies for therapy of ovarian cancer: conventional vs targeted. S. Gupta, Y. Pathak, M. K. Gupta, S. P. Vyas. Artif Cells Nanomed Biotechnol. 2019. V. 47. P. 4066-4088. https://doi.org/10.1080/21691401.2019.1677680.

3. Smithson C. R., Schneider S. M. Ibrutinib: a new targeted therapy for hematologic cancers. Clin J Oncol Nurs. 2015. V. 19. P. E47-51. https://doi.org/10.1188/15.CJON.E47-E51.

4. Ali I. Nano drugs: novel agents for cancer chemo-therapy. Curr Cancer Drug Targets. 2011. V. 11. P. 130.

5. Clinical applications of nanomedicine in cancer therapy. M. Norouzi, M. Amerian, F. Atyabi et al. Drug Discov Today. 2019. P. S1359-6446(19)30377-0. https://doi.org/10.1016/j.drudis.2019.09.017. [Epub ahead of print] Review. 
6. Вплив Іфітинібу на складові хроматину та стан антиоксидантної системи в карциномі Герена та незмінених тканинах матки. Л. Б. Бондаренко, Т. А. Карацуба, О. О. Хавич та ін. Фармакологія та лікарська токсикологія. 2019. Т. 13. С. 322-330.

7. Протипухлинна активність похідних хіназоліну на недрібноклітинному раку легенів людини (підкапсульний тест). Н. О. Мєшкова, О.О. Хавич, Г. М. Олійник та ін. Матеріали V Національного з'їзду фармакологів України. 18-20 жовтня 2017, м. Запоріжжя. 2017. С. 94-95.

8. Экспериментальная оценка противоопухолевых препаратов в СССР и США; под ред. 3. П. Софьиной и др. Москва : Медицина, 1980. 296 с.

9. Current Protocols in Toxicology; ed. M. Maines. N. Y. : John Wiley \& Sons, Inc., 2005. 2758 p.

10. Великов В. А. Молекулярная биология. Практическое руководство: учеб. пособие для студ. биол. факультетов и факультетов нано- и биомед. технологий, обучающихся по направлению «Биология (020400)», «Биология-пед (050100)», «Биотехнические системы и технологии (200100)», «Медицинская физика (011200)» и по специальности «Биоинженерия и биоинформатика (020501)». Саратов : Издательство «Саратовский источник», 2013. 84 с.: ил.

11. Смирнов Н. В. Фракционирование гистоновых белков печени крысы. Современные методы в биологии; ред. В. Н. Орехович. Москва : Медицина, 1977. С. 349-353.

12. Agarose Gel Electrophoresis for the Separation of DNA Fragments. P. Lee, J. Costumbrado, C. Hsu, Y. Kim. Journal of Visualized Experiments. 2012. V. 62. P. 57-59.

13. Sedlak J., Lindsay R. H. Estimation of total, protein-bound, and non protein sulfhydryl groups in tissue with Ellman's reagent. Analytical Biochemistry, 1968. V. 25. P. 192-205.

14. DMBA-induced cytotoxicity in lymphoid and nonlymphoid organs of B6C3F1 mice: relation of cell death to target cell intracellular calcium and DNA damage. S. W. Burchiel, D. A. Davis, S. D. et al. Toxicol. Appl. Pharmacol. 1992. V. 113. P. 126-132.

15. Wang X., Yongke Lu Y., Cederbaum A. I. Induction of Cytochrome P450 2E1 Increases Hepatotoxicity Caused by Fas Agonistic Jo2 Antibody in Mice. Hepatology. 2005. V. 42. P. 400-411.

16. Erol A. Systemic DNA damage response and metabolic syndrome as a premalignant state. Curr. Mol. Med. 2010. V. 3. P. 321-334.

17. Комбінований вплив екзогенних оксидів азоту та малих доз іонізуючої радіації на розвиток генетичної нестабільності та утворення вільнорадикальних сполук при пухлинному рості. О. А. Главін, Б. І. Геращенко, Н. М. Рябченко та ін. Сучасні проблеми токсикології. 2011. Т. 5. C. $108-109$.

18. Лукашова О. П. Действие ионизирующей радиации и препарата «Этопозид» на процессы апоптоза и ультраструктуры клеток карциномы Герена. Український радіологічний журнал. 2013. T. 21. С. 56-63.

19. Патент США: Індукуючі апоптоз засоби для лікування злоякісних пухлин та іммунологічних і аутоіммунних захворювань. Автори патента: Сауэрс Э. Дж. (US), Ван C. (US), Салливан Дж. (US), Канзер А. (US), Уэндт М. Д. (US), Джадд Э. С. (US), Тао Чжи-фу (US). C07D471/04, C07D463/00,A61P35/00, A61K31/437. URL: http://www.findpatent.ru/patent/266/ 2662812.html

20. Ceramide-induced cell death in malignant cells. A. Carpinteiro, C. Dumitru, M. Schenck, E. Gulbins. Cancer Letters. 2008. V. 264. P. 1-10.

21. Вплив поєднаної дії іонізуючого випромінювання та хіміопрепаратів на вміст проапоптозного ліпіду цераміду в карциномі Герена. Т. Сегеда, Н. Мітряєва, Т. Бакай, Л. Гребіник. Вісник Львівського університету. Серія біологічна. 2012. Випуск 60. С. 111-116.

22. Bulow J. F. RNA-DNA ratios as indicators of growth rates in fish: A review. In: R. C. Summerfelt, G. E. Hall, editors. The age and growth of fish. The lowa State University Press; Ames, lowa: 1987. P. 45-64.

23. Robinson S. M., Ware D. Ontogenetic development of growth rates in larval Pacific herring, Clupea harengus pallasi, measured with RNA/DNA ratios in the Strait of Georgia, British Columbia. Can. J. Fish. Aquat. Sci. 1988. V. 45. P. 1422-1429.

24. Новичков Е. В., Вотинцев А. А. Значение гистоспектрофотометрических параметров опухоли в прогнозе метастазирования серозной овариальной карциномы. Пермский медицинский журнал. 2006. Т. 23. С. 112-137.

25. Морфология внутренних органов и опухоли лабораторных крыс с перевитым раком печени Pc-1 при пероральном введении флавоноидсодержащих экстрактов аврана лекарственного (Gratiola Officinalis L. ) и кукурузы антоциановой (Zea Mays L.). Н. А. Наволокин, Н. В. Полуконова, Г. Н. Маслякова и др. Саратовский научно-медицинский журнал. 2013. Т. 9. С. 74-81.

26. Traganos F., Darzynkiewicz Z., Melamed M. R. The ratio of RNA to total nucleic acid content as a quantitative measure of unbalanced cell growth. Cytometry: The Journal of the International Society for Analytical Cytology. 1982. V. 2. P. 212-218.

27. Hutcheson R., Rocic P. The Metabolic Syndrome, Oxidative Stress, Environment, and Cardiovascular Disease: The Great Exploration. Experimental Diabetes Research. 2012. V. 2012. P. 1-13. 
Л. Б. Бондаренко, Т. А. Карацуба, О. О. Хавич, Г. М.Шаяхметова, Н. І. Шарикіна, В. М. Коваленко, О. І. Харченко, Н. М. Сергійчук, М. М. Калачінська Вплив 2-(3-аліл-4-оксо-3,4-дигідро-хіназолін-2-іл-сульфоніл)-N(2,6-дихлорфеніл)-цераміду на складові хроматину та стан антиоксидантної системи в саркомі 45 і незмінених тканинах шкіри щурів

Стрімке поширення онкологічних захворювань у XXI столітті в усьому світі зумовлює інтенсифікацію хіміотерапевтичного лікування даної патології зі застосуванням усе нових і нових цитотоксичних і цитостатичних агентів. Однак це зумовлює зростання й числа побічних ефектів і небажаних наслідків використання даних препаратів. Неспецифічна дія щодо всього організму пацієнта та висока токсичність даної групи лікарських засобів, зокрема, їхня кардіо-, нефро- та нейротоксичність, а також відсутність достатньої інформації щодо віддалених наслідків введення протипухлинних засобів на стан прилеглих тканин, які не були захоплені інвазією пухлини, зумовлюють нагальну потребу в системному вивченні біохімічних змін не лише в пухлині, але й поза її межами. У попередніх експериментах нами було проведене вивчення впливу протипухлинного похідного хіназоліну на складові хроматину, процеси фрагментації ДНК, вміст небілкових і пов'язаних з білками SH-груп у карциномі Герена та незмінених тканинах матки й виявлено специфічність його впливу на низку показників виключно в тканині пухлини. У зв'язку з цим актуальним є з'ясування, чи є виявлена специфічність похідного хіназоліну характерною лише для тканини матки, чи вона поширюється й на інші тканини організму.

Мета дослідження - вивчити вплив 2-(3-аліл-4-оксо-3,4-дигідро-хіназолін-2-іл-сульфоніл)-N(2,6-дихлорфеніл)-цераміду (АХДЦ) на ДНК, РНК, білки хроматину, процеси фрагментації ДНК, вміст небілкових і пов'язаних з білками SH-груп у саркомі 45 і незмінених тканинах шкіри щурів.

Тварини були розподілені на 3 групи по 6 тварин у кожній: 1 - інтактні щури; 2 - негативний контроль (саркома 45); 3 - саркома $45+$ АХДЦ (29,93 мг/кг).

Вивчення впливу АХДЦ на ДНК, РНК, білки хроматину, процеси фрагментації ДНК, вміст небілкових і пов'язаних з білками SH-груп у саркомі 45 і незмінених тканинах шкіри показало, що дана сполука вірогідно змінювала більшість досліджуваних показників як порівняно з інтактними тваринами, так і з саркомою 45 без лікування. Специфічність впливу АХДЦ на клітини пухлин була найвираженішою щодо ДНК-фрагментації та змін вмісту РНК, співвідношень РНК/ДНК і РНК/НК. Щодо впливу на вміст SH-груп у тканині саркоми 45 і неуражених пухлиною тканинах шкіри, то в даному випадку ефект АХДЦ був протилежним за напрямком стосовно змін вмісту небілкових і пов'язаних з білками SH-груп.

Ключові слова: 2-(3-аліл-4-оксо-3,4-дигідро-хіназолін-2-іл-сульфоніл)-N-(2,6-дихлорфеніл)церамід, саркома 45, ДНК, РНК, фрагментація, антиоксидантна система

\section{Л. Б. Бондаренко, Т. А. Карацуба, О. А. Хавич, А. М. Шаяхметова, Н. И. Шарыкина, В. Н. Коваленко, О. И. Харченко, Н. Н. Сергийчук, М. Н. Калачинская Влияние 2-(3-аллил-4-оксо-3,4-дигидро-хиназолин-2-ил-сульфонил)-N- (2,6 -дихлорфенил)-церамида на составляющие хроматина и состояние антиоксидантной системы в саркоме 45 и неизмененных тканях кожи крыс}

Стремительное распространение онкологических заболеваний в XXI веке во всем мире вызывает интенсификацию химиотерапевтического лечения данной патологии с применением все новых и новых цитотоксических и цитостатических агентов. Однако это вызывает рост и числа побочных эффектов и нежелательных последствий использования данных препаратов. Неспецифическое действие в отношении всего организма пациента и высокая токсичность данной группы лекарственных средств, в частности, их кардио-, нефро- и нейротоксичность, а также отсутствие достаточной информации об отдаленных последствиях применения противоопухолевых средств на состояние прилегающих тканей, не захваченных инвазией опухоли, обусловливают настоятельную потребность в системном изучении биохимических изменений не только в опухоли, но и за ее пределами. В предыдущих экспериментах нами было проведено изучение влияния противоопухолевого производного хиназолина на составляющие хроматина, процессы фрагментации ДНК, содержание небелковых и связанных с белками SH-групп в карциноме Герена и неизмененных тканях матки и выявлена специфичность его влияния в отношении ряда показателей исключительно в опухолевой ткани. В связи с этим актуален вопрос, является ли обнаруженная специфичность производного хиназолина характерной только для ткани матки, или же она распространяется и на другие ткани организма.

Цель исследования - изучить влияние 2-(3-аллил-4-оксо-3,4-дигидро-хиназолин-2-ил-сульфонил)-N-(2,6-дихлорфенил)-церамида (АХДЦ) на ДНК, РНК, белки хроматина, процессы фрагментации ДНК, содержание небелковых и связанных с белками SH-групп в саркоме 45 и неизмененных тканях кожи крыс.

Животные были разделены на 3 группы по 6 в каждой: 1 - интактные крысы; 2 - отрицательный контроль (саркома 45); 3 - саркома 45 + АХДЦ (29,93 мг / кг).

Изучение влияния АХДЦ на ДНК, РНК, белки хроматина, процессы фрагментации ДНК, содержание небелковых и связанных с белками SH-групп в саркоме 45 и неизмененных тканях кожи показало, что данное соединение достоверно изменяло большинство исследуемых показателей как по 
сравнению с интактными животными, так и с саркомой 45 без лечения. При этом специфичность влияния АХДЦ на клетки опухолей была наиболее выраженной в случае ДНК-фрагментации и изменений содержания РНК, соотношений РНК/ДНК и РНК/НК. Что касается влияния на содержание SH-групп в ткани саркомы 45 и не пораженных опухолью тканях кожи, то в данном случае эффект АХДЦ был противоположным по направлению относительно изменений содержания небелковых и

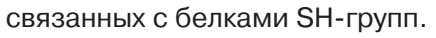

Ключевые слова: 2-(3-аллил-4-оксо-3,4-дигидро-хиназолин-2-ил-сульфонил)-N-

(2,6-дихлорфенил)-церамид, саркома 45, ДНК, РНК, фрагментация, антиоксидантная система

\section{B. Bondarenko, T. A. Karatsuba, O. O. Khavich, G. M. Shayakhmetova, N. I. Sharykina, V. M. Kovalenko, O. I. Kharchenko, N. M. Serhiichuk, M. M. Kalachinskaya \\ Effect of 2-(3-allyl-4-oxo-3,4-dihydro-quinazolin-2-yl-sulfonyl)-N-(2,6- dichlorophenyl)-ceramide on chromatin constituents and the state of the antioxidant system in sarcoma $\mathbf{4 5}$ and unchanged rat skin tissues}

The rapid spread of oncological diseases in the XXI century throughout the world causes the intensification of pathology chemotherapeutic treatment with the use of new cytotoxic and cytostatic agents. However, this causes an increase in the number of side effects and undesirable consequences of these drugs using. The nonspecific effect on the entire patient's organism and the high toxicity of this group of drugs, in particular, their cardio-, nephro- and neurotoxicity, as well as the lack of sufficient information on the long-term effects of antitumor agents on the state of adjacent tissues without tumor invasion, cause the urgent need for a systematic study of biochemical changes not only in the tumor, but also beyond. In previous experiments, we studied the effect of the antitumor quinazoline derivative on chromatin constituents, DNA fragmentation, non-protein and protein-bound SH groups in Guerin's carcinoma and unchanged uterine tissues, and revealed the specificity of its effect with respect to a number of indicators exclusively in tumor tissue. In this regard, it is relevant to determine whether the detected specificity of the quinazoline derivative is characteristic only of uterine tissue, or whether it extends to other tissues of the body.

The aim of the study - to evaluate the effect of 2-(3-allyl-4-oxo-3,4-dihydro-quinazolin-2-yl-sulfonyl)$\mathrm{N}$-(2,6-dichlorophenyl)-ceramide (AQDC) on DNA, RNA, chromatin proteins, DNA fragmentation processes, the content of non-protein and protein-associated $\mathrm{SH}$-groups in sarcoma 45 and unchanged rat skin tissues.

Animals were divided into 3 groups of 6 in each: 1 - intact rats; 2 - negative control (sarcoma 45); 3 sarcoma 45 + AQDC $(29,93 \mathrm{mg} / \mathrm{kg})$.

A study of the effect of AQDC on DNA, RNA, chromatin proteins, DNA fragmentation processes, the content of non-protein and protein-associated $\mathrm{SH}$-groups in sarcoma 45 and unchanged skin tissues showed that this drug significantly changed the majority of the studied parameters both in comparison with intact animals and with sarcoma 45 without treatment. Moreover, the specificity of the effect of AQDC on tumor cells was most pronounced in the case of DNA fragmentation and changes in RNA content, RNA/ DNA and RNA/NA ratios. As for the effect on the content of SH-groups in sarcoma tissue 45 and nontumor-affected skin tissues, in this case the effect of AQDC was opposite direction for changes in the content of non-protein and protein-associated SH-groups.

Key words: 2-(3-allyl-4-oxo-3,4-dihydro-quinazolin-2-yl-sulfonyl)-N-(2,6-dichlorophenyl)-ceramide, sarcoma 45, DNA, RNA, fragmentation, antioxidant system

Надійшла: 26 грудня 2019 р.

Прийнята до друку: 12 лютого 2020 р.

Контактна особа: Бондаренко Л. Б., ДУ «Інститут фармакології та токсикології НАМНУ», буд. 14, вул. Антона Цедіка, м. Київ, 03057. Тел.: + 380444564256. 